\title{
Erratum to: European Conference on Thermoelectrics 2013
}

\author{
THE PUBLISHER
}

1.-233 SPRING STREET, NEW YORK, NY 10013, USA

\section{Erratum to: Journal of ELECTRONIC \\ MATERIALS}

DOI: $10.1007 / \mathrm{s} 11664-014-3078-5$

Thermoelectric Coolers with Sintered Silver Interconnects

JULIAN KÄHLER, ANDREJ STRANZ, ANDREAS WAAG, and ERWIN PEINER

DOI: $10.1007 / \mathrm{s} 11664-014-3101-\mathrm{x}$

Crystallization and Transport Properties of Amorphous Cr-Si Thin Film Thermoelectrics

S.V. NOVIKOV, A.T. BURKOV, and J. SCHUMANN

DOI: $10.1007 / \mathrm{s} 11664-014-3139-9$

Anisotropic Thermopower of the Kondo

Insulator $\mathrm{CeRu}_{4} \mathrm{Sn}_{6}$

J. HÄNEL, H. WINKLER, M. IKEDA,

J. LARREA J., V. MARTELLI, A. PROKOFIEV,

E. BAUER, and S. PASCHEN
DOI: $10.1007 / \mathrm{s} 11664-014-3157-7$

Heat Sinks for Miniature Thermoelectric Coolers: Selection and Characterization

\section{SEMENYUK}

These articles were inadvertently published in Volume 43, Number 6 of the Journal of Electronic Materials. They belong in the special issue European Conference on Thermoelectrics 2013, Volume 43, Number 10. 